\title{
Pengaruh Probiotik Bakteri Asam Laktat dalam Air Minum Terhadap Konversi Pakan Ayam Broiler
}

\section{Effect of Lactic Acid Bacteria Probiotics in Drinking Water on Broiler Feed Conversion}

\author{
Nanda Kholifatul Azizah", Sarmanu², Budi Utomo³, Emy Koestanti Sabdoningrum4, \\ Widya Paramitha Lokapirnasari ${ }^{4}$, Koesnoto Supranianondo ${ }^{4}$ \\ ${ }^{1}$ Mahasiswa, 2 Departemen Anatomi Veteriner, ${ }^{3}$ Departemen Reproduksi Veteriner, \\ ${ }^{4}$ Departemen Peternakan, Fakultas Kedokteran Hewan, Universitas Airlangga \\ Corresponding author: nanda.kholifatul.azizah-2015@fkh.unair.ac.id
}

\begin{abstract}
This study aimed to determine the effect of probiotics of lactic acid bacteria in drinking water on feed consumption, weight gain and feed conversion ratio of broiler chickens. This research is an experimental research. The experimental animals used in this study were 28 male broiler chickens strain Cobb 700 aged 20 days. P0 was not given the addition of probiotic lactic acid bacteria, $\mathrm{P} 1$ was given the addition of probiotic lactic acid bacteria Lactobacillus acidophilus in 1 $\mathrm{ml}$ /liter drinking water, P2 was given the addition of probiotic lactic acid bacteria Lactobacillus casei in drinking water $1 \mathrm{ml} /$ liter, P3 was given the addition of probiotic lactic acid bacteria Lactobacillus fermentum in drinking water $1 \mathrm{ml} /$ liter, $\mathrm{P} 4$ was given the addition of probiotic lactic acid bacteria Lactobacillus plantarum in drinking water $1 \mathrm{ml} /$ liter, P5 was given the addition of probiotic lactic acid bacteria Pediococcus in drinking water $1 \mathrm{ml} /$ liter, P6 was given the addition of probiotic mix lactic acid bacteria in drinking water $1 \mathrm{ml} /$ liter. Collecting data for the last 1 week by weighing the remaining consumption of feed given and weight gain of broiler chickens. The data obtained were analyzed using the Analysis of Variant (ANOVA) statistical method and continued with Duncan. Based on the results of the calculation of the amount of feed consumption and weight gain in broiler chickens, it showed that the administration of probiotic lactic acid bacteria $1 \mathrm{ml} /$ liter of water in broiler chickens could increase body weight gain, reduce feed conversion rates but did not reduce broiler feed consumption $(\mathrm{p}<0.05)$.
\end{abstract}

Keywords: lactic acid bacteria, feed consumption, weight gain, feed conversion

Received: 08-09-2020 Revised: 09-10-2020 Accepted: 10-11-2020

\section{PENDAHULUAN}

Satu komoditi unggas yang memberikan kontribusi besar dalam memenuhi kebutuhan protein asal hewani bagi masyarakat Indonesia. Ayam broiler adalah jenis ternak unggas yang memiliki laju pertumbuhan yang cepat karena dapat dipanen pada umur 5 minggu (Umam dkk., 2015).

Konversi ransum merupakan suatu ukuran yang dapat digunakan untuk menilai efisiensi penggunaan dan kualitas ransum (Rasyaf dalam Fahrudin dkk., 2016). Berbagai upaya diperlukan untuk memperbaiki pakan, salah satunya adalah penggunaan probiotik sebagai campuran pakan maupun air minum untuk meningkatkan produktifitas ternak (Daud dkk., 2007).

Probiotik adalah suatu bahan yang mengandung mikroba hidup yang digunakan untuk mengatur 
keseimbangan mikroba di dalam saluran pencernaan (Pramudia dkk., 2013). Probiotik dapat menekan pertumbuhan mikroba patogen sehingga mikroba yang menguntungkan dapat berkembang dengan baik (Kompiang, 2009).

Probiotik yang banyak dimanfaatkan adalah bakteri asam laktat. Efektivitas bakteri asam laktat dalam menghambat bakteri patogen dipengaruhi oleh kepadatan bakteri asam laktat, strain bakteri asam laktat, dan komposisi media (Afriani, 2010). Dalam penelitian ini menggunakan lima jenis bakteri asam laktat yaitu Lactobacillus acidhopillus, Lactobacillus casei, Lactobacillus fermentum, Lactobacillus plantarum dan Pediococcus.

Berdasarkan latar belakang penelitian diatas maka perlu dilakukan penelitian penggunaan probiotik yaitu : Lactobacillus acidhopillus, Lactobacillus casei, Lactobacillus fermentum, Lactobacillus plantarum dan Pediococcus yang dicampur dalam air minum dengan harapan dapat menurunkan konsumsi pakan, konversi pakan serta meningkatkan pertambahan berat badan ayam broiler.

\section{METODE}

\section{Tempat dan waktu penelitian}

Penelitian ini dilaksanakan pada bulan Mei - Juli 2018. Penelitian dilaksanakan di tiga tempat yaitu Laboratorium Pakan Ternak Departemen Peternakan, Laboratorium Agribisnis, dan Kandang Hewan Coba Fakultas Kedokteran Hewan Universitas Airlangga.

\section{Bahan dan materi penelitian}

Bahan yang digunakan dalam penelitian ini antara lain ayam broiler strain Cobb 700 sebanyak 28 ekor, pakan komersial ayam fase starter dan finisher, air minum yang dicampur probiotik dengan dosis $1 \mathrm{ml} /$ liter air,
Lysol 3\%, vaksin Newcastle Disease (ND) strain Lasota.

\section{Materi penelitian}

Alat yang digunakan dalam penelitian ini adalah tempat pakan dan minum, timbangan digital, plastik, alatalat pembersih kandang, hand sprayer, lampu penerangan $25 \mathrm{~W}$, kandang postal dan 28 unit kandang baterai.

\section{Perlakuan hewan coba}

Tahap perlakuan diberikan pada ayam broiler umur 21 hari sebanyak 28 ekor yang diacak menjadi 7 perlakuan, setiap perlakuan terdiri dari 4 ekor. Ayam broiler diberi pakan sebanyak dua kali dalam sehari, pagi dan sore. Perlakuan ayam broiler dicampur dalam air minum dengan jenis probotik bakteri asam laktat yang berbeda pada setiap perlakuan dosis $1 \mathrm{ml} /$ liter air yang diberikan secara ad libitum. Pengumpulan data mulai ayam broiler umur 28 hari dilakukan dengan cara menimbang ayam dan sisa pakan setiap tujuh hari sekali sampai ayam berumur 35 hari.

\section{Konsumsi pakan}

Penghitungan Konsumsi pakan menggunakan rumus:

Konsumsi pakan (g/ekor) $=$ Pakan yang diberikan - pakan yang sisa

Penghitungan rata-rata pertambahan bobot badan menurut Bagenal (1978) dengan menggunakan rumus:

$$
\mathrm{PBB}=\mathrm{BBt}-\mathrm{BBt}-1
$$

Keterangan:

$\mathrm{BBt}=$ Berat badan pada waktu $\mathrm{t}$

BBt $-1=$ Berat badan pada waktu yang lalu

$\mathrm{t}=$ Dalam peternakan ayam biasanya dalam kurun waktu satu minggu 
Perhitungan konversi pakan

Penghitungan nilai konversi menggunakan rumus:

$$
\text { Konversi Pakan }=\frac{\text { Konsumsi pakan }(\mathrm{g})}{\operatorname{PBB}(\mathrm{g})}
$$

\section{Analisis data}

Data yang diperoleh dari penelitian ini diuji normalitas menggunakan uji Kolmogorov Smirnov. Jika data berdistribusi normal dianalisis menggunakan Analysis of Variant (ANOVA) dilanjutkan dengan Duncan. Jika data berdistribusi tidak normal dilakukan analisis menggunakan Krusal Wallis dan dilanjutkan dengan Mann Withney. Analisis data menggunakan perangkat komputer SPSS 16 for Windows.

\section{HASIL DAN PEMBAHASAN} Konsumsi pakan

Tabel 1. Rata-rata Konsumsi Pakan ayam broiler

\begin{tabular}{cc}
\hline Perlakuan & $\begin{array}{c}\text { Konsumsi Pakan } \\
\text { (gram/ekor/hari) } \\
\text { [mean } \pm \text { SD] }\end{array}$ \\
\hline P0 & $127.75^{\mathrm{a}} \pm 14.315$ \\
P1 & $149.00^{\mathrm{c}} \pm 4.830$ \\
P2 & $138.00^{\mathrm{abc}} \pm 6.000$ \\
P3 & $130.00^{\mathrm{ab}} \pm 12.247$ \\
P4 & $142.50^{\mathrm{abc}} \pm 1.000$ \\
P5 & $146.25^{\mathrm{bc}} \pm 18.062$ \\
P6 & $188.50^{\mathrm{d}} \pm 8.888$ \\
\hline
\end{tabular}

Hasil menunjukkan bahwa
perlakuan P1, P2, P3, P4, P5 terhadap konsumsi pakan tidak memiliki perbedaan yang signifikan terhadap perlakuan P0 dan antar perlakuan P1 sampai P5. Hal ini menunjukkan bahwa pemberian probiotik bakteri asam laktat secara tunggal dalam air minum tidak mempengaruhi konsumsi pakan ayam broiler secara signifikan. Konsumsi pakan merupakan faktor yang sangat berpengaruh dalam menentukan keberhasilan pemeliharaan ayam broiler.

Perlakuan P6 mixpro kombinasi ke lima jenis bakteri asam laktat menunjukkan konsumsi tertinggi dari perlakuan lainnya. Bakteri asam laktat mempunyai fungsi membentuk asam laktat, meningkatkan aktifitas bakteri normal di usus, mampu menstimulasi enzim saluran pencernaan dan menstimulasi pengeluaran garam empedu. Fungsi yang berbeda ini menyebabkan adanya interaksi yang baik antara probiotik, memberikan efek yang sinergis dalam mencerna pakan selain itu interaksi antar spesies akan menyebabkan ketahanan terhadap gerak peristaltik usus, sehingga campuran bakteri ini akan kompetitif terhadap mikroba patogen, sehingga lebih efektif dalam pengolahan pakan. Hal ini memberikan arti bahwa Lactobacillus yang masuk ke saluran pencernaan ayam dapat bertahan hidup dan berkembang dalam alat pencernaan ayam sehingga dapat membantu meningkatkan proses pencernaan. Lactobacillus menghasilkan enzim yang sangat diperlukan dalam sistem pencernaan antara lain sukrase, lactase, dan peptidase yang juga diperlukan untuk meningkatkan protease sehingga pemanfaatan pakan ternak dapat terjadi secara optimal dan mempunyai nilai keuntungan ekonomis yang cukup tinggi.

Bakteri asam laktat secara efektif bisa meningkatkan aktivitas enzim yang membantu proses pencernaan makanan dalam saluran pencernaan secara enzimatis seperti amilolitik, proteolitik, lipolitik dan selulolitik (Manin, 2010).

Pemberian probiotik cair kedalam air minum terhadap konsumsi pakan menunjukkan optimalnya pemberian probiotik akan meningkatkan daya cerna organ pencernaan, sehingga akan meningkatkan konsumsi pakan. Daya cerna ayam pedaging meningkat yang menyebabkan absorpsi zat makanan 
lebih cepat dan kosongnya saluran pencernaan lebih cepat sehingga ayam pedaging lebih cepat lapar (Barrow dalam Lokapirnasari dkk., 2016). Probiotik dapat memperbaiki saluran pencernaan dan meningkatkan kecernaan pakan dengan cara menekan bakteri patogen dalam saluran pencernaan sehingga mendukung perkembangan bakteri menguntungkan yang membantu penyerapan zat-zat makanan. Probiotik dapat mengubah pergerakan mucin dan populasi mikroba didalam usus halus ayam, sehingga keberadaaanya dapat meningkatkan fungsi dan kesehatan usus, memperbaiki mikroflora pada sekum, serta meningkatkan penyerapan zat makanan (Daud, 2005).

\section{Pertambahan berat badan}

Tabel 2. Rata - rata pertambahan berat badan ayam broiler

\begin{tabular}{cc}
\hline Perlakuan & $\begin{array}{c}\text { Pertambahan Berat } \\
\text { Badan } \\
\text { (gram/ekor/hari) } \\
\text { [mean } \pm \text { SD] }\end{array}$ \\
\hline P0 & $57.75^{\mathrm{a}} \pm 6.551$ \\
P1 & $73.50^{\mathrm{b}} \pm 2.380$ \\
P2 & $65.50^{\mathrm{ab}} \pm 3.109$ \\
P3 & $62.00^{\mathrm{a}} \pm 5.598$ \\
P4 & $71.00^{\mathrm{b}} \pm .000$ \\
P5 & $72.75^{\mathrm{b}} \pm 8.808$ \\
P6 & $110.50^{\mathrm{c}} \pm 5.066$ \\
\hline Hasil & menunjukkan bahwa
\end{tabular}

perlakuan P1, P2, P3, P4, P5 terhadap pertambahan berat badan memiliki perbedaan terhadap perlakuan PO, tetapi tidak memiliki peredaan yang signifikan terhadap antar perlakuan P1 sampai P5. Hal ini menunjukkan bahwa pemberian probiotik bakteri asam laktat secara tunggal dalam air minum sedikit berpengaruh terhadap pertambahan berat badan ayam broiler.

Perlakuan P6 mix probiotik memiliki nilai pertambahan berat badan tertinggi diantara semua perlakuan yaitu sebesar 110.5 gram/ekor/hari.
Pertambahan berat badan ini sejalan dengan konsumsi pakan perlakuan P6 yang tinggi. Hal ini menunjukkan bahwa pakan yang dikonsumsi oleh ayam cukup efisien dan banyak digunakan untuk pertumbuhan. Bakteri asam laktat dalam fungsinya sebagai probiotik dapat mengoptimalkan penyerapan nutrisi sehingga berat badan dapat meningkat.

Siregar dalam Astini dkk. (2014) menyatakan bahwa pertambahan bobot badan dipengaruhi oleh jumlah pakan yang dikonsumsi, semakin tinggi tingkat konsumsi pakan, semakin tinggi pula pertambahan bobot badan yang dihasilkan dan sebaliknya semakin rendah konsumsi maka semakin rendah pula pertambahan bobot badan. Hal ini didukung oleh pendapat Wahju dalam Fajri (2012), bahwa untuk mencapai tingkat pertumbuhan optimal sesuai dengan potensi genetik, diperlukan makanan yang mengandung unsur gizi secara kualitatif dan kuantitatif, dengan demikian ada hubungan kecepatan pertumbuhan dengan jumlah konsumsi makanan.

Probiotik meningkatkan aktivitas enzim pencernaan sehingga penguraian dan penyerapan makanan menjadi lebih sempurna sehingga pakan yang diserap dengan baik tersebut dapat dimanfaatkan oleh ayam untuk pertumbuhan jaringan dan peningkatan berat badan. Probiotik berperan meningkatkan produk metabolisme yang bermanfaat bagi tubuh ternak. Produk metabolisme tersebut dimanfaatkan secara maksimal untuk membentuk atau menambah ukuran jaringan baru.

Lactobacillus $s p$ dapat meningkatkan konsumsi pakan serta retensi zat pakan, sehingga secara langsung zat metabolit tersebut dimanfaatkan oleh tubuh ternak untuk menambah ukuran jaringan baru (Nahashon dkk. dalam Kusuma dkk., 2016). Hasil dari pertumbuhan ataupun 
perkembangan jaringan baru tersebut berpengaruh terhadap kenaikan berat badan ayam pedaging (Gsianturi dalam Astuti dkk., 2015).

\section{Konversi pakan}

Tabe1 3. Rata - rata nilai konversi pakan

\begin{tabular}{cc} 
Perlakuan & $\begin{array}{c}\text { Rasio Konversi Pakan } \\
\text { [mean } \pm \text { SD] }\end{array}$ \\
\hline P0 & $2.20^{\mathrm{d}} \pm 0.00000$ \\
P1 & $2.00^{\mathrm{b}} \pm 0.00000$ \\
P2 & $2.09^{\mathrm{c}} \pm 0.00500$ \\
P3 & $2.10^{\mathrm{c}} \pm 0.00000$ \\
P4 & $2.00^{\mathrm{b}} \pm 0.00000$ \\
P5 & $2.00^{\mathrm{b}} \pm 0.00000$ \\
P6 & $1.70^{\mathrm{a}} \pm 0.00000$ \\
\hline
\end{tabular}

Hasil menunjukkan bahwa perlakuan P1, P2, P3, P4, P5 terhadap nilai konversi pakan tidak memiliki perbedaan yang signifikan antar perlakuan P1 sampai P5 tetapi menunjukkan hasil yang lebih rendah dari PO. Hal ini dapat dikatakan bahwa pemberian probiotik tunggal mampu mempengaruhi nilai konversi pakan ayam broiler.

Konversi pakan terendah terdapat pada perlakuan P6 (mix probiotik) yang menunjukkan perbedaan signifikan dari perlakuan lainnya. Nilai konversi pakan menunjukkan tingkat efisiensi penggunaan pakan, semakin rendah nilai konversi pakan, semakin tinggi nilai efisiensi pakan dan semakin ekonomis. Perlakuan P6 mengandung gabungan bakteri asam laktat yang terdiri dari L. acidophilus, L. casei, $L$. fermentum, L. plantarum, Pediococcus sp. dengan fungsi membentuk asam laktat, meningkatkan aktifitas bakteri normal yang ada di usus, mampu menstimulasi enzim pada saluran pencernaan dan menstimulasi pengeluaran garam empedu yang apabila semua bahan bakteri asam laktat dicampur. Hal ini menunjukkan bahwa adanya interaksi yang baik antar probiotik, memberikan efek yang sinergis dalam mencerna makanan untuk membentuk jaringan baru.

Probiotik meningkatkan aktivitas enzim pencernaan sehingga penyerapan makanan menjadi lebih sempurna dengan makin luasnya area absorbsi sebab probiotik dapat mempengaruhi anatomi usus yaitu villi usus menjadi lebih panjang dan densitasnya lebih padat. Dimana proses absorbsi hasil pencernaan terjadi di permukaan villi yang memiliki banyak mikrovili (Suprajitna dkk. dalam Astuti dkk., 2015). Jin dalam Astuti dkk. (2015) menyatakan bahwa keberadaan probiotik dalam pakan dapat meningkatkan aktivitas enzimatis dan meningkatkan aktivitas pencernaan. Akibatnya, zat nutrisi seperti lemak, protein, dan karbohidrat yang biasanya banyak terbuang dalam feses akan menjadi berkurang. Hal ini memberikan indikasi bahwa perlakuan dengan kombinasi bakteri asam laktat dalam air minum merupakan perlakuan paling efisien untuk mencapai pertumbuhan yang maksimal dan menguntungkan apabila dibandingkan perlakuan lainnya. Semakin tinggi nilai konversi pakan menunjukkan semakin banyak pakan yang dibutuhkan untuk meningkatkan berat badan per satuan berat. Demikian juga sebaliknya semakin rendah nilai konversi pakan berarti kualitas pakan semakin baik.

\section{KESIMPULAN}

Berdasarkan hasil perhitungan jumlah konsumsi pakan dan pertambahan berat badan menunjukkan bahwa pemberian probiotik bakteri asam laktat dengan dosis $1 \mathrm{ml} /$ liter air minum pada ayam broiler dapat meningkatkan pertambahan berat badan, menurunkan nilai konversi pakan tetapi tidak berpengaruh pada konsumsi pakan ayam broiler.

DAFTAR PUSTAKA 
Afriani. 2010. Pengaruh Penggunaan Starter Bakteri Asam Laktat Lactobacillus plantarum dan Lactobacillus fermentum terhadap Total Bakteri Asam Laktat, Kadar Asam, dan Nilai pH Dadih Susu Sapi. Jurnal Ilmiah Ilmu-Ilmu Peternakan. Vol. XIII, No. 6.

Astini, W., M.A. Al Arif., S. Mulyati. 2014. The Potensial Of Commercial Probiotic to Broiler's Weight Gain, Feed Consumtion and Feed Conversation of Broiler. AGROVETERINER Vol. 2 No.2.

Astuti, F. K., Woro, B., Osfar, S. 2015. Pengaruh penambahan probiotik cair dalam pakan terhadap penampilan produksi pada ayam pedaging. J-PAL. Vol. 6, No.2.

Daud, M. 2005. Performan Ayam Pedaging Yang Diberi Probiotik dan Prebiotik Dalam Ransum. Jurnal Ilmu Ternak. Vol. 5 No. 2 (75 - 79).

Daud, M., W.G. Piliang., dan I.P. Kompiang. 2007. Persentase dan Kualitas Ayam Pedaging yang Diberi Probiotik dan Prebiotik dalam Ransum. Jurnal Ilmu Ternak dan Veteriner 12(3): 167-174.

Fahrudin, A., Wiwin, T., dan I. Heni. 2016. Konsumsi Ransum, Pertambahan Bobot Badan dan Konversi Ransum Ayam Lokal di Jimmy's Farm Cipanas Kabupaten Cianjur. Fakultas Peternakan Universitas Padjajaran.

Fajri, N. 2012. Pertambahan Berat Badan, Konsumsi dan Konversi Pakan Broiler yang Mendapat Ransum Mengandung Berbagai Level Tepung Daun Katuk (Sauropus Androgynus). Makalah Hasil Penelitian. Fakultas Perternakan
Universitas Hasanuddin Makassar. Makassar.

Kompiang, I.P. 2009. Pemanfaatan Mikroorganisme Sebagai Probiotik Untuk Meningkatkan Produksi Ternak Unggas di Indonesia. Laporan Penelitian. Pusat Penelitian dan Pengembangan Peternakan Bogor.

Kusuma, H.A., A. Mukhtar, R. Dewanti. 2016. Pengaruh Tingkat Pembatasn Pemberian Pakan (Restricted Feeding) Terhadap Performan Ayam Broiler Jantan. Sains Peternakan. Vol. 14 (1).

Lokaprinasari, W.P., Anggun, R., dan Hana, E. 2016. Potensi Penambahan Bakteri Asam Laktat Lactobacillus casei dan Lactobacillus rhamnosus Terhadap Konsumsi Pakan dan Konversi Pakan Ayam Pedaging. AGROVETERINER Vol. 5 No. 1

Manin, F. 2010. Potensi Lactobacillus acidophilus dan Lactobacillus fermentum Dari Saluran Pencernaan Ayam Buras Asal Lahan Gambut Sebagai Sumber Probiotik. Jurnal Ilmiah Ilmu - Ilmu Peternakan. XIII, (5): 221-228.

Pramudia, A. Mangisah, dan B .I. Sukamto. 2013. Kecernaan Lemak Kasar Dan Energi Metabolisme Pada Itik Magelang Jantan Yang Diberi Ransum Dengan Level Protein Dan Probiotik Berbeda. Animal Agriculture Journal 2(4): 148-160.

Umam, M.K., H.S. Prayogi., dan V.M.A. Nurgiartiningsih. 2015. The Performance of Broiler Rearing in System Stage Floor and Double Floor. Jurnal Ilmu-Ilmu Peternakan 24(3): 79-87. 